\title{
Descriptive and multivariable analysis of the water parameters quality of Sfax sewage treatment plant after rehabilitation
}

\author{
Dalel Belhaj ${ }^{\mathrm{a}^{*}}$, Ikram Jaabiri ${ }^{\mathrm{b}}$, Nesrine Turki ${ }^{\mathrm{c}}$, Chafai Azri ${ }^{\mathrm{d}}$, Monem Kallel ${ }^{\mathrm{e}}$ \\ and Habib Ayadi ${ }^{\mathrm{f}}$ \\ ${ }^{a *}$, University of Sfax-Tunisia, Faculty of Sciences, Department of Life Sciences, Laboratory of Biodiversity and \\ Aquatic Ecosystems, Ecology and Planktonology, Street Soukra Km 3.5 BP 1171 CP 3000. \\ ${ }^{b, c, e}$ University of Sfax-Tunisia, ENIS. Laboratory of Water-Energy-Environment. Street Soukra Km 3.5. BP \\ 1173 CP 3038. \\ ${ }^{e}$ University of Sfax-Tunisia, Department of Earth Sciences, Street Soukra Km 3.5 BP 802, CP 3000.
}

\begin{abstract}
This study detailed the effect of simultaneous multiple intrinsic and extrinsic factors on the characteristics of Sfax activated sludge wastewater treatment plant (WWTP), located in Southern East Tunisia. The plant performance was evaluated through descriptive and statistical analysis of quantity and quality data of both raw wastewaters and treated effluent over a period of three years (2008 - 2010). Despite the rehabilitation, poor performance was shown to be attributed to raw wastewaters quality, civilization populations, bad functioning of the aerators and the industrial fallouts and deposits. Therefore, the downstream values of $B O D_{5}, C O D, S S, F C, F S, T K N$ and TP are enough to achieve a final effluent that would meet the Tunisian standards limit. Multiple regression analysis showed that removal efficiencies of $B O D_{5}, C O D$ and $S S$ can be predicted to reasonable accuracy $\left(R^{2}=0.973,0.946\right.$ and 0.925, respectively). Goodness of the model fit to the data was also evaluated through the relationship between the residuals and the model predicted values of $\mathrm{BOD}_{5} r, \mathrm{CODr}$ and SSr. The advantage of this model is that it would allow a better process control.
\end{abstract}

Key words: Activated sludge; Multiple regression analysis; Wastewater treatment plant; Water quality parameters

\section{Introduction}

The increasing pace of industrialization, urbanization and population growth that our planet has faced over the last one hundred years has increased environmental pollution and affected water quality. Water quality is a term used to describe the chemical, physical and biological characteristics of water with respect to its suitability for a particular use. Water quality is affected by a wide range of natural and anthropogenic influences. Natural processes (hydrological, physical, chemical and biological) may affect the characteristics and concentration of chemical elements and compounds in freshwater. In addition, there are also anthropogenic impacts that affect water quality (Dione, 2002), such as human-induced point and nonpoint pollution sources. In this context, wastewater treatment has become one of the most important environmental issues, insofar as it reduces pollution of natural water resources - i.e. groundwater, transitional water and coastal water promotes sustainable water reuse, protects the aquatic environment, and improves the status of aquatic ecosystems. However, for making them effective, it is pertinent to monitor the performance of the wastewater treatment plants (WWTPs) on a regular basis (Hanbay et al., 2008). The organic pollution indicator variables such as biochemical oxygen demand (BOD), chemical oxygen demand (COD), total Kjeldahl nitrogen (TKN), and ammonical nitrogen $\left(\mathrm{NH}_{4}-\mathrm{N}\right)$ are considered as the key parameters for describing the wastewater characteristics and their corresponding ratio in the effluent to influent wastewater as a measure of the overall performance for a conventional WWTP.

Within cities of the south eastern Mediterranean Sea, natural water resources are limited, whereas their demand is constantly increasing. Therefore, non-conventional water resources became important to reduce waste discharges to surface waters and to improve potential water resource. In Tunisia, the reuse of treated wastewater (TWW) has been adopted since the 1960s. Treatment of this potential source becomes imperative before use.

Activated sludge is the most common biological technology used for domestic wastewater treatment in industrialized countries around the world. Hence, it has been adopted since the 2006s by WWTP of Sfax city (Tunisia). The considered plant was an aerated lagoon, established in 1983 with average daily capacities of $24,000 \mathrm{~m}^{3}$. Several studies have been proven its poor performance (Azri et al., 2007; Ouali et al., 2009). In order to improve the plant performance, the activated sludge has been the process adopted for its rehabilitation. This process consists of biological reactors, where microorganisms are grown while degrading particulate and dissolved wastes. Separation of the microbial solids produced in these reactors is achieved by sedimentation, with a portion of the settled solids wasted from the system and a portion recycled back to the bioreactors to 
maintain high solids concentrations and rates of reaction. The distribution of these functions can vary within an activated sludge duo to seasonal flow rates variations (Hamed et al., 2004), seasonal variability of biomass density (Patricia et al., 2010) and aeration conditions. Such variations may result in an operational risk impact on the plant and an improper operation of WWTP may lead to discharge of contaminated effluents causing serious environmental and public health problems. Accordingly, environmental regulations set restrictions on the quality of effluent that must be met by any WWTP.

In this context, the present study deals with the evaluation of the performance of the wastewater treatment plant of Sfax city (Tunisia) after its rehabilitation and retails the influence of multiple intrinsic and extrinsic factors on its characteristics. In order to achieve this objective, exhaustive data from a previous threeyear experiment were statistically treated. Statistical tools such as forward stepwise regression models were employed to predict the plant performance based on past observations of certain key product quality parameters. These results would simplify design decisions to optimize pollutant removal from urban wastewaters.

\section{Materials \& methods}

\subsection{Description of Sfax wastewater treatment plant facilities after rehabilitation}

Since 2006, low activated sludge process has been adopted by Sfax wastewater treatment plant. The plant treats the sewage discharge derived from approximately 526, 800 inhabitants, here by referred to as population equivalents (PEs), including mostly municipal sewage and approximately $30 \%$ industrial input. The process flow of the examined plant is illustrated in Fig. 1.

The original sewage, composed of municipal and industrial wastewaters, first passed through the mechanical screen and aerated grit chamber. Then, the sewage was directed to the primary sedimentation tanks. Sewage from the primary treatment is passed for biological or secondary treatment. The secondary treatment adopted is consisting of on alternating anoxic/aerobic (A/A) bioreactors helping simultaneous removal of nitrogen and phosphorus. Air is supplied into the aerobic reactors with 16 aerators for the growth and reproduction of micro-organisms which assimilate and decompose the organic matter in the sewage. The dissolved oxygen was controlled at $2 \mathrm{mg} \mathrm{O}_{2} / \mathrm{L}$ and the hydraulic retention time of the activated sludge was approximately $40 \mathrm{~h}$. Finally, the effluent from the A/A reactors is settled in secondary sedimentation tanks. $70 \%$ of the secondary effluent was directly discharged to a close sea, the rest to a nearby El Hajeb in order to reuse for irrigation. Part of the settled sludge was returned to the bioreactors and the remaining part was pumped into a storage tank as excess sludge. After being dewatered, the excess sludge was carried away in drying beds. The treatment capability of this STP was $49,500 \mathrm{~m}^{3} /$ day. The A/A bioreactors were operated with a solid residence time (SRT) of approximately 3 days.

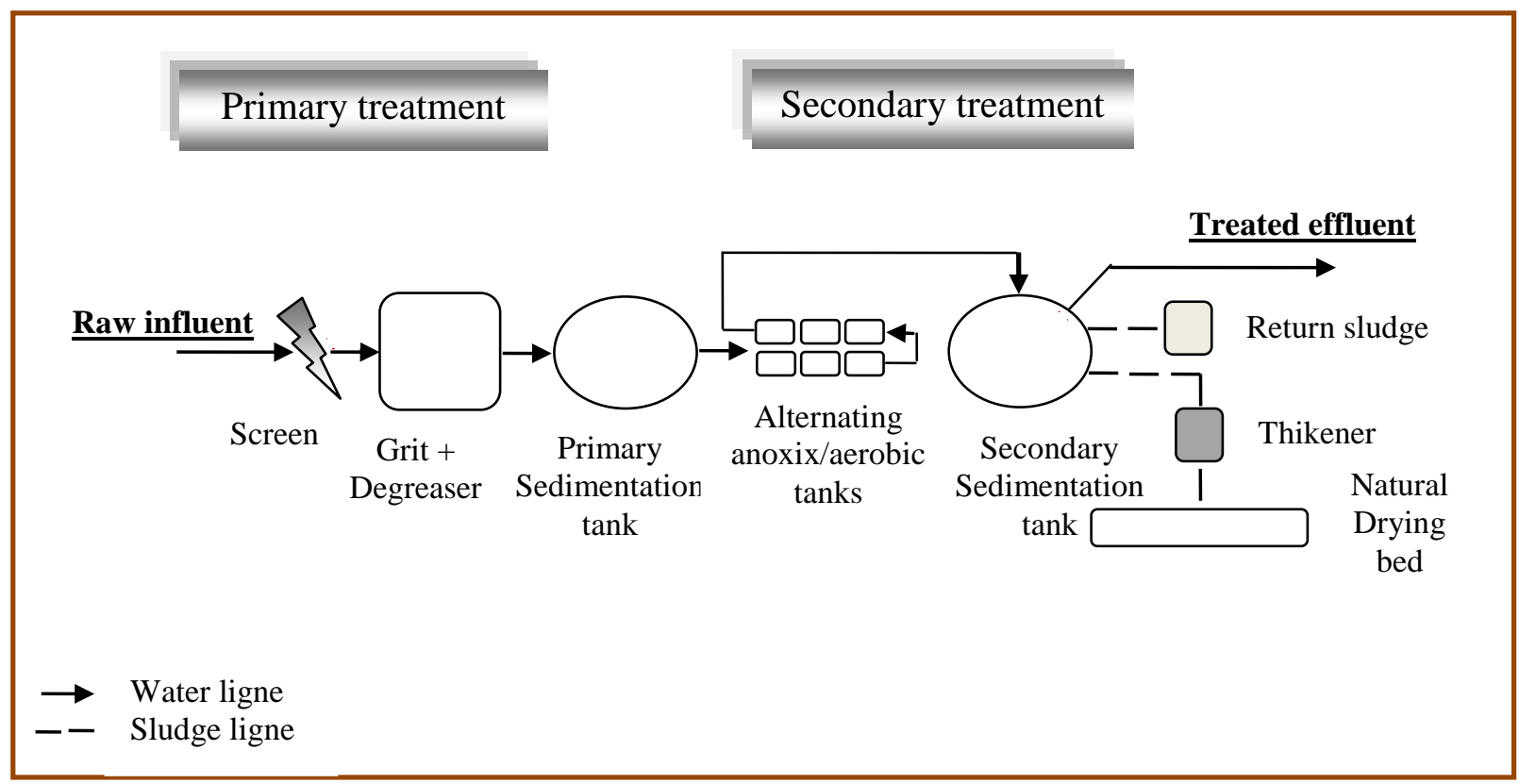

Figure 1. Localization and schematic representation of Sfax wastewater treatment plant

\subsection{Monitored parameters and analytical methods}

Study was carried for a period of three years (2008 - 2010) and samples were collected on weekly basis from raw wastewater and treated effluent. 
Physico-chemical characterization of wastewater was made according to French standard (AFNOR, 1997). $\mathrm{pH}$ was analysed in a 1:10 (w/v) water-soluble extract. The chemical oxygen demand (COD) was determined with the reactor digestion using a HACH DR 2010 analyzer. The 5-day biological oxygen demand $\left(\mathrm{BOD}_{5}\right)$ was determined by the manometric method with a respirometer (BSB-controlled Model OxiTop WTW). Moreover, total nitrogen (TKN) was measured by the Kjeldahl method (Gerhard Automatic system). The Phosphorus content (TP) was measured calorimetrically by atomic absorption (HITACHI, Z-6100 model). The mixed liquor suspending solid (MLSS) was determined by wastewater settling for $2 \mathrm{~h}$. The suspended solids (SS) were determined by filtration and drying at $110^{\circ} \mathrm{C}$. Organic matter in raw wastewater were analysed by gas chromatography coupled with mass spectrometry (GC-MS). The GC-MS analyses were carried out with gas chromatography (GC, Hewlett-Packard 6890 Series, Agilent Technology) equipped with a mass spectrometer (MS, Hewlett-Packard 5973 Mass Selective Detector, Agilent Technology). Data of wastewater temperature was measured on the site using mercury thermometer. Information about air temperature and rainfall was obtained from the Meteorological Agency. Faecal coliforms (FC) and faecal streptococci (FS) were estimated according to ISO 4832 (1991) and AFNOR (NF T90-411, 1989) water standard methods.

Removal efficiency of studied plant was determined as the percentage of decrease in influent with respect to effluent for each parameter measured.

For wastewater characterization, three replicates were used in each parameter. For colony forming unit (CFU) estimation, two replicates and three Petri dishes were made for each substrate concentration with all bacterial strains. The means and standard deviations of analysis/determination results were calculated using the XLSTAT (version 7.5.2)

All statistical analysis was performed using the ITCF statistical software package (STATIT-CF, 1987). Simple correlations were used to determine if significant relationships existed between parameters concentrations in raw wastewater (dependent variables) and treated effluent (independent variables). Stepwise multiple regressions were used to determine which parameters were significant in forecasting the dependent variables (biological oxygen demand removal $\left(\mathrm{BOD}_{5} \mathrm{r}\right)$, chemical oxygen demand removal $\left(\mathrm{COD}_{\mathrm{r}}\right)$ and suspending solids removal $\left(\mathrm{SS}_{\mathrm{r}}\right)$ ). Once the independent variables, significantly associated with dependent variables, the coefficients of determination $\left(\mathrm{R}^{2}\right)$ for regression models were calculated. The relative contribution of each independent variable to the variation of dependent variables removal efficiencies in selected models was determined. The models were tested for goodness of fit by using the Student's $t$ test and the $F$ test. After the models have been constructed, they were graphically analysed for goodness of fit by plotting the actual against the predicted results.

\subsection{Performance evaluation of the plant}

\section{Results and discussion}

\subsubsection{Wastewater flow rate}

Monthly evolutions of wastewater volumes showed irregular variation depending not only on water consumption rates of the population but also on the precipitation inflow in the city which combined sewer systems (Fig. 2a). The average monthly wastewater volume increased from $1 \times 10^{6} \mathrm{~m}^{3}$, in 2008 to $1,5 \times 10^{6} \mathrm{~m}^{3}$, in 2010 . The corresponding average daily volume varied between 29,500 and $40,500 \mathrm{~m}^{3}$, which is comparable to the plant capacity $\left(40,000\right.$ to $\left.50,000 \mathrm{~m}^{3}\right)$.
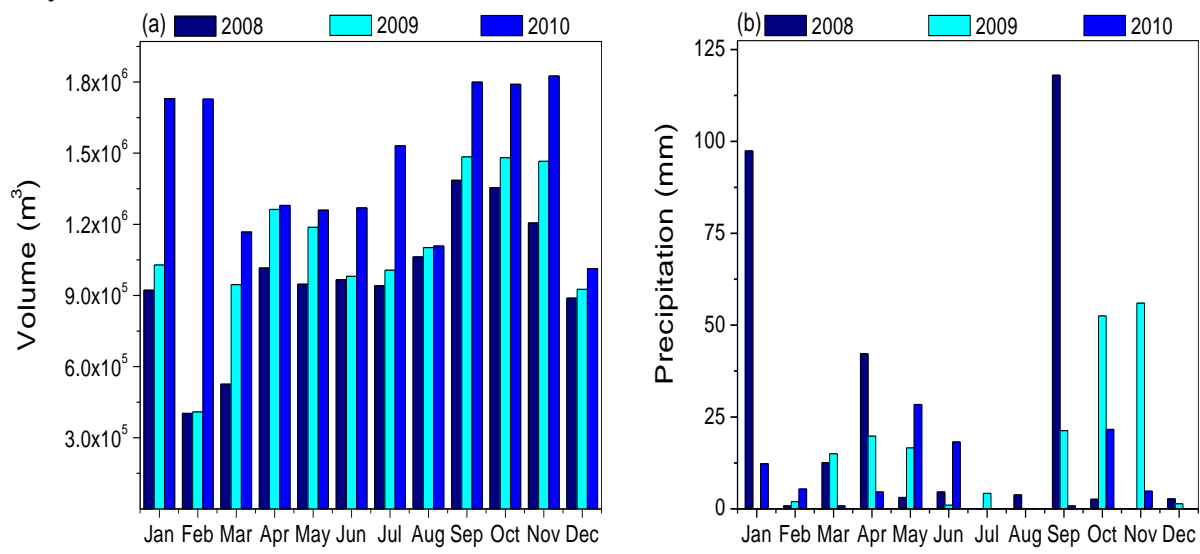

Figure 2. Evolution of wastewater volumes (a) and precipitation (b)

The largest monthly volumes of wastewater are observed in fall season (September, October and November) of the studied period (between $1.2 \times 10^{6}$ and $1.8 \times 10^{6} \mathrm{~m}^{3}$ ), characterized by important storm runoff discharge rates (Fig. 2a); while the fewest monthly volumes (except for January and February 2010) are showed in winter season. This might be owing to the least amount of precipitation (Fig. 2b) and to the relatively low 
water consumption rates of population over this period. Despite the importance of precipitation in January 2008 , wastewater volumes are relatively small. This is due to the character of regional precipitations (weak downpours spread out over prolonged periods). Concerning the summer season, where precipitation are very limited and even with the more important consumption rates, wastewater volumes remain below registered volumes in the fall season.

\subsection{2. pH}

$\mathrm{pH}$ is a fundamental factor for water quality which mainly depends upon a variety of chemical factors, e.g., dissolved gases, organic acids, humic fractions and inorganic salts. The decomposition of organic fractions of wastewater, mainly by microbes in water, produces some acidic species of mineralized organic materials $\left(\mathrm{CO}_{2}\right.$, ammonia, $\mathrm{NO}_{3}{ }^{-}$and organic acids) which plays an important role in shifting of $\mathrm{pH}$ scale of treated water. During the study period (2008 - 2010), the treated effluent $\mathrm{pH}$ is mostly higher than that for the raw wastewater (Fig. 3). Measured $\mathrm{pH}$ values were consistently increased by between 0.2 and 0.9 units giving relatively stable monthly average $\mathrm{pH}$ effluent between 7.8 and 7.9 .

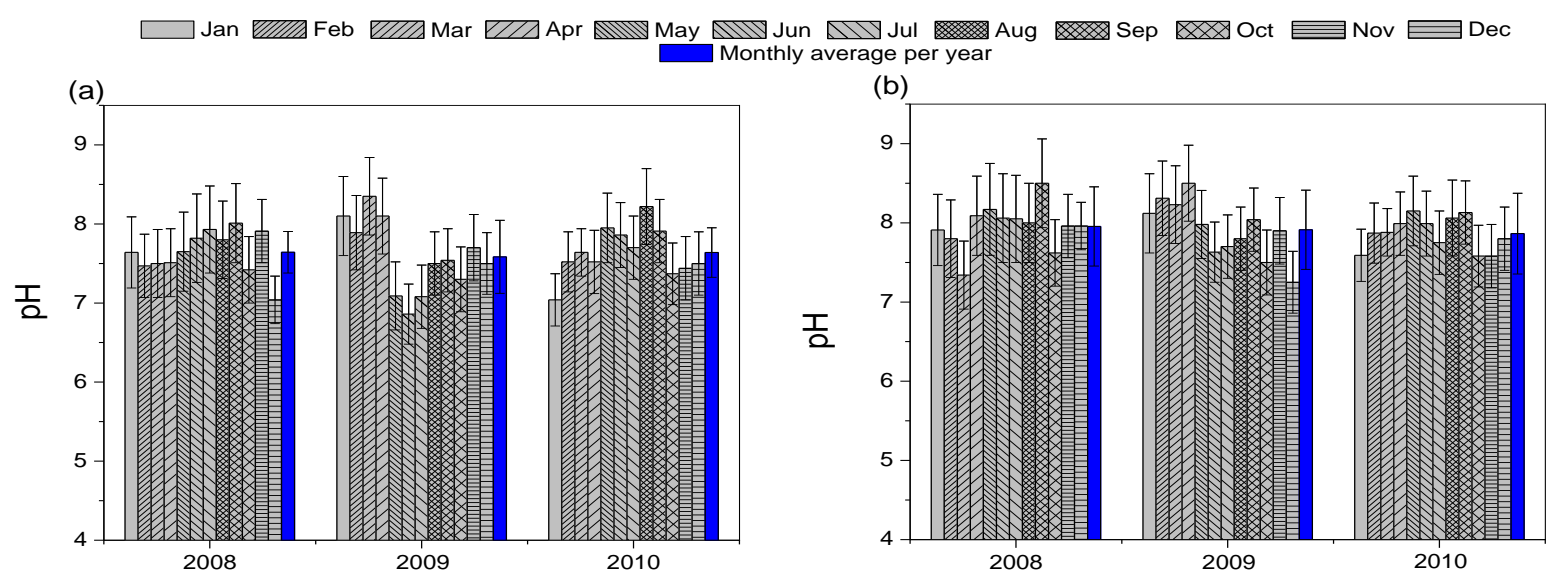

Figure 3. Evolution of $\mathrm{pH}$ in raw wastewater (a) and treated effluent (b)

\subsubsection{Temperature}

During the investigation study, the average values of wastewater temperature are $18.8^{\circ} \mathrm{C}, 19.5^{\circ} \mathrm{C}$ and $19.6^{\circ} \mathrm{C}$, respectively (Fig. 4a), and this were in the range with the meteorological means of $24.7^{\circ} \mathrm{C}, 25^{\circ} \mathrm{C}$ and 25 (Fig. 4b). The highest wastewater temperature (between $25^{\circ} \mathrm{C}$ and $29{ }^{\circ} \mathrm{C}$ ) was reached in July-August, and the lowest values (between $11^{\circ} \mathrm{C}$ and $12.5^{\circ} \mathrm{C}$ ) was recorded in February, similar to the air temperature.

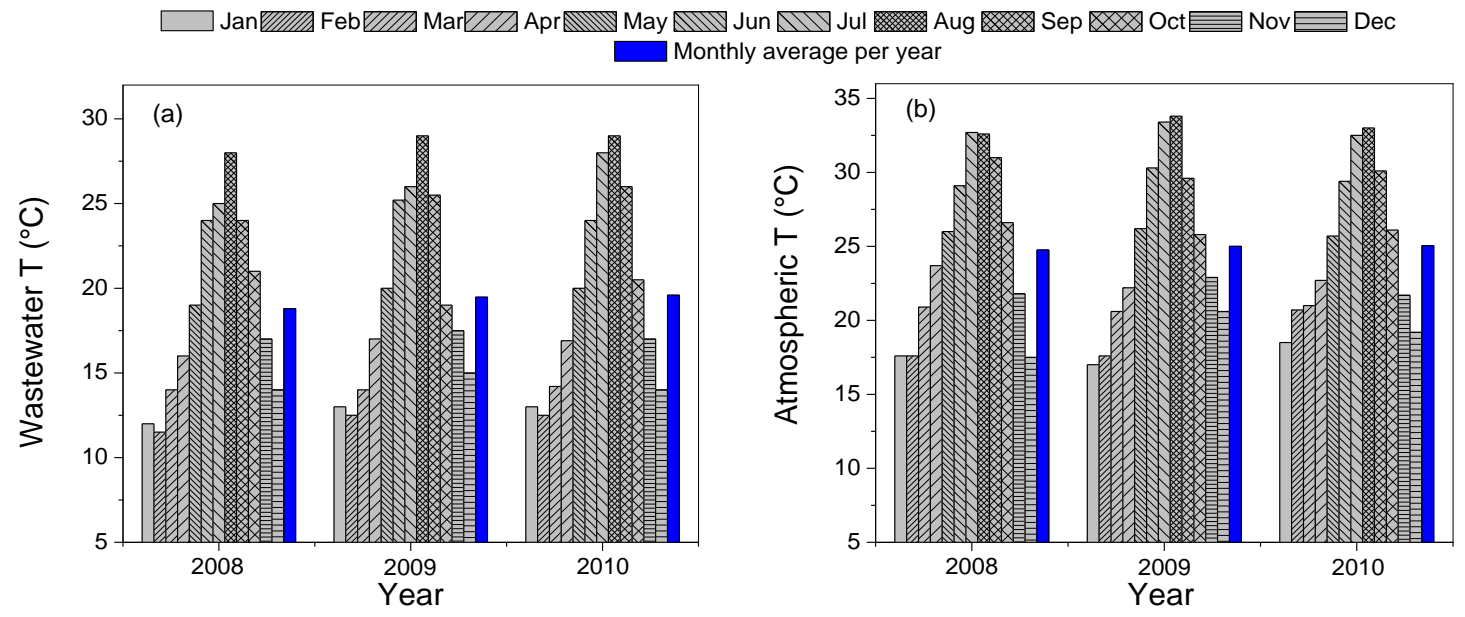

Figure 4. Trend of raw wastewater (a) and atmospheric (b) temperature

\subsubsection{Organic matter}

COD, BOD and SS are an important indicator of organic loads of urban wastewater. The monthly average evolution of COD in raw wastewater, during the studied period 2008 - 2010, is showed in Figure 5a. Its general trend is characterized by two antagonistic evolution phases: the first is represented by an increasing rate 
and relatively significant monthly average values around $1072 \mathrm{mg} \mathrm{O}_{2} / \mathrm{L}$ while the second shows a decreasing rate and monthly average values close to $895 \mathrm{mg} \mathrm{O}_{2} / \mathrm{L}$. Maximum values of 1621,1596 and $1642 \mathrm{mg} \mathrm{O}_{2} / \mathrm{L}$ are observed in February, April and July 2009, respectively. In order to investigate type and origins of organic compounds during this entire period of high loading rate of organic matters (in terms of COD), GC-MS analyses were carried out. Results suggested that the largest group of organic matters were short and long-chain fatty acids and their methylsilyl ester (Nos. 18-26 in Table 1) originated from human excreta, soaps, food oils and fats. To the best of our knowledge, Sfax is the fourth largest olive oil producer in the world (Ministère de l'Agriculture et des Ressources Hydrauliques, 2008), and its industrial activity generates a huge volume of olive mill wastewater (OMW). Thus, OMW is an acidic effluent ( $\mathrm{pH} 4.5$ - 5.5) with an excessive high organic load which includes high levels of phytotoxic and microbial inhibitor compounds, such as phenolic and long-chain fatty acids. It is of interest that emphasize be laid on the presence of phenolic compounds (Nos. 8 in Table 1) in the raw wastewater which constitute a significant part of the organic content of olive wastewater (Hachicha et al., 2009). Hence, the seasonal olive mill wastewater (OMW) production, from January to the end of April, discharged to sewers was one of the most common reasons in the gradual increase of COD in the raw waste water during February and April.

Table 1. Identification of the main organic compounds in raw wastewater evidenced by GC-MS

\begin{tabular}{|c|c|c|c|}
\hline Type & No. & Compound name & RT \\
\hline Ketone & 1. & Bicyclo [2.2.1] heptan-2-one & 9.98 \\
\hline \multirow[t]{4}{*}{ Alkyl aromatics } & 2. & Tridecane & 13.08 \\
\hline & 3. & Tetradecane & 15.51 \\
\hline & 4. & Pentadecane & 17.91 \\
\hline & 5. & Hexadecane & 20.24 \\
\hline \multirow[t]{2}{*}{ Alcohol } & 6. & Bicyclo [2.2.1] heptan-2-ol & 10.39 \\
\hline & 7. & 1-Dodecanol & 17.31 \\
\hline Phenolic & 8. & Phenol, 2,4,-bis (1,1-dimethyethyl) & 18.29 \\
\hline \multirow[t]{5}{*}{ Nitrogenous compound } & 9. & 1H-Indole & 13.25 \\
\hline & 10. & 1H-Indole, 5-methyl & 15.55 \\
\hline & 11. & Benzothioquinoline & 20.18 \\
\hline & 12. & Caffeine & 26.04 \\
\hline & 13. & 3,3-dihydro-6,7-dimethoxyisoquinoline 2 -oxide & 44.03 \\
\hline \multirow[t]{2}{*}{ Ester } & 14. & 1,2-benzenedicarboxylic acid, dibutyl ester & 28.14 \\
\hline & 15. & 1,2-Benzenedicarboxylic acid, bis 2-ethylhexyl) ester & 38.27 \\
\hline \multirow[t]{2}{*}{ Resin acid } & 16. & Dehydroabietic acid, trimethylsilyl ester & 35.99 \\
\hline & 17. & Hydromethylsiloxane & 37.01 \\
\hline \multirow[t]{9}{*}{ Organic acids } & 18. & Dodecanoic acid, trimethylsilyl ester & 21.46 \\
\hline & 19. & Tetradecanoic acid, trimethylsilyl ester & 25.68 \\
\hline & 20. & Hexadecanoic acid & 27.85 \\
\hline & 21. & Palmitoleic acid 1 trimethylsilyl ester & 29.20 \\
\hline & 22. & Hexadecanoic acid, trimethylsilyl ester & 29.55 \\
\hline & 23. & 9,12 -octadecadienoic acid $(\mathrm{Z}, \mathrm{Z})$ & 31.17 \\
\hline & 24. & 9-octadecenoic acid $(\mathrm{Z})$ & 31.25 \\
\hline & 25. & Oleic acid, trimethylsilyl ester & 32.69 \\
\hline & 26. & Octadecanoic acid, trimethylsilyl ester & 33.09 \\
\hline
\end{tabular}

With the occasional rainfall that occurred in July 2009, we can deduct that this maxima of COD are dependent of rainwater effect. They can be attributed to a dumping of particular industrial wastes. The next largest group found in the raw wastewater were Nitrogenous compounds such as caffeine (Nos. 12 in Table 1) and indoles (Nos. 9 and 10 in Table 1) which can be largely attributed to protein, peptide or amino sugars (Berwick et al., 2007). A foaming which occurred seasonally during this crucial juncture probably contributed to periodically high Nitrogen loading. Consequently, the settle ability of activated sludge was deteriorated as shown in the gradual increase of Sludge Volume Index (SVI) until it reached a steady state at $280 \mathrm{ml} / \mathrm{g}$. The raw wastewater during this entire period also showed relatively high abundances of alkyl aromatics (Nos. 2-5 in Table 1) which are common constituents of petroleum and many of the industrial hydrocarbon based chemicals produced from it (e.g., lubricants, plastics, paints, adhesives).

The variation of monthly average COD values, in treated effluent showed a trend which is not consistent with that of raw wastewaters (Fig. 5b). As regards to the results of the statistical analysis, lack correlation between raw wastewater and treated effluent $\left(R^{2}=0.149\right)$ ensures the dependence of downstream conditions on the other factors than upstream conditions. This fact could be assigned to an irregular work of aerators functioning. During the studied period, the monthly COD values exceeding Tunisian standards $(90 \mathrm{mg}$ $\mathrm{O}_{2} / \mathrm{L}$ ) confirm a chemical disequilibrium of the system. 


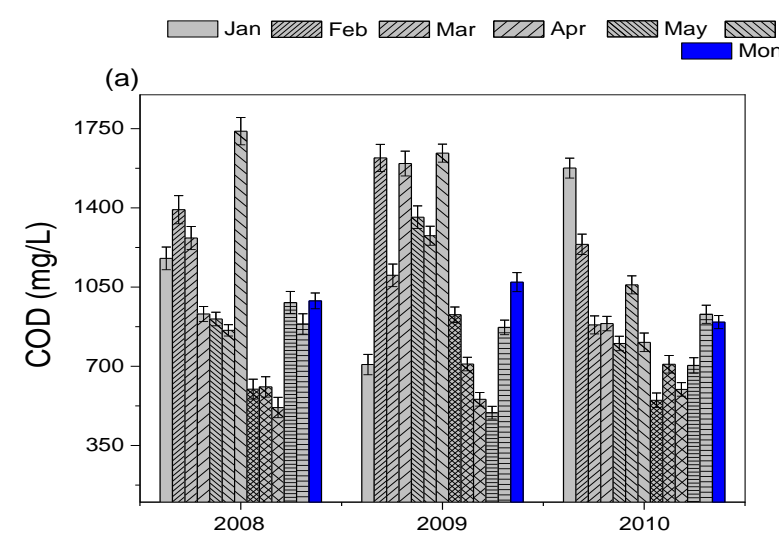
Monthly average per year
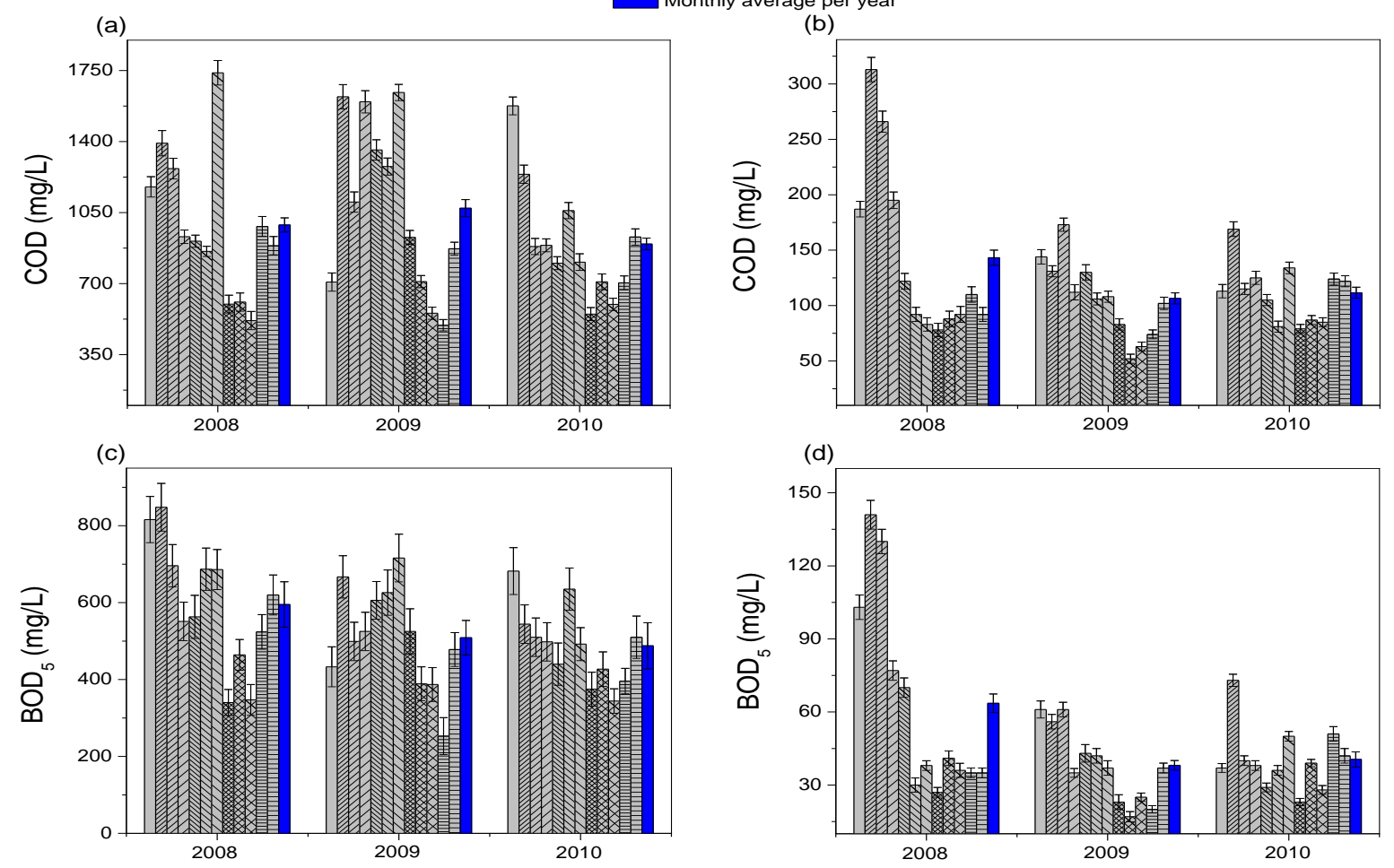

Figure 5. Evolution of COD in raw wastewater (a) and treated effluent (b), and evolution of $\mathrm{BOD}_{5}$ in raw wastewater (c) and treated effluent (d)

Average $\mathrm{BOD}_{5}$ values in raw wastewater also varied between 2008 and 2010 (Fig. 5c). Its general trend is not similar to that of COD. It is characterized by a decreasing rate from 595 to $487 \mathrm{mg} \mathrm{O}_{2} / \mathrm{L}$. Moreover, it is important to note that over the period 2008-2010, the representative BOD daily average load was shown to be lower than the recommended value of $21,600 \mathrm{Kg}$ per day.

In treated effluent, the monthly average $\mathrm{BOD}_{5}$ values showed, in general, the same decreasing trend as in raw wastewater (Fig. 5d). The decreasing rate of values is much more important in treated effluents, especially during the first period (2008 - 2009). Over the studied period, despite the conformity of upstream values to the recommendations, the downstream values are relatively higher than Tunisian standards $(30 \mathrm{mg}$ $\left.\mathrm{O}_{2} / \mathrm{L}\right)$.

Absence of linearity $\left(\mathrm{R}^{2}=0.3615\right)$ between monthly average $\mathrm{BOD}_{5}$ in raw wastewater and treated effluent could be attributed to a particular behaviour of organic matter in the wastewater treatment plant. This situation might cause massive production of biomass in the aeration tanks, which affects overall levels of dissolved oxygen.

Over the period $2008-2010$, the evolution of monthly SS concentrations in raw wastewater showed similar trend to that of COD. It is characterized by two evolution phases (Fig. 6a): the first is represented by an increasing rate and relatively significant monthly average values around $725 \mathrm{mg} / \mathrm{L}$ while the second shows a decreasing rate and monthly average values close to $536 \mathrm{mg} / \mathrm{L}$. Maximum values of 1353,1343 and $1459 \mathrm{mg} / \mathrm{L}$ are observed in February, May and July 2009, respectively.

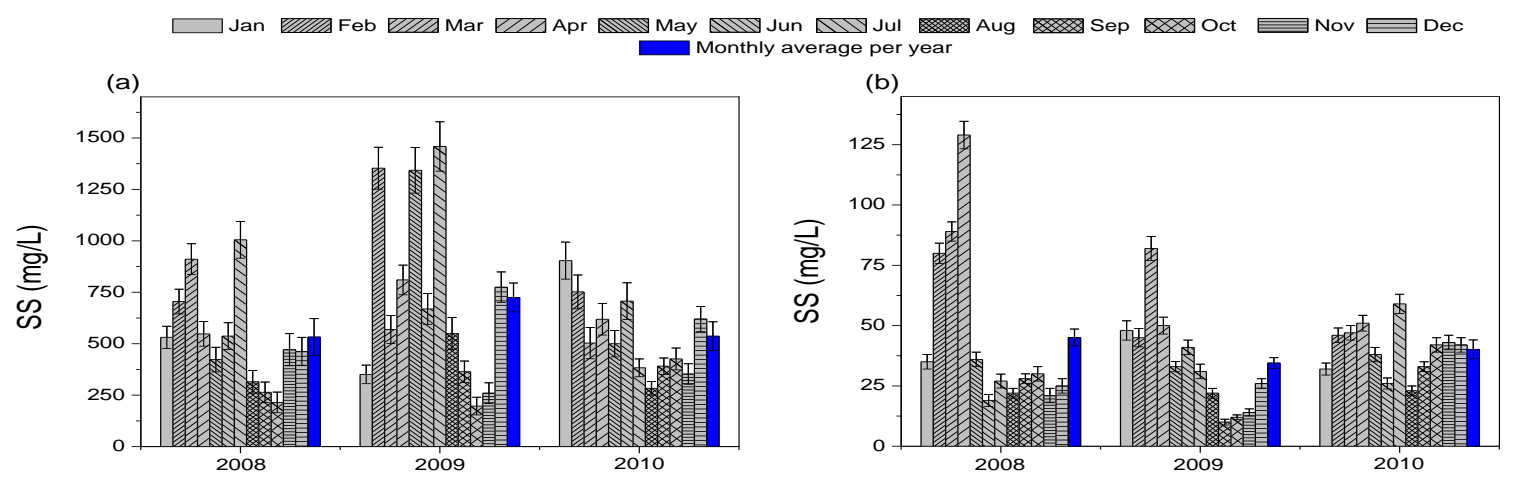

Figure 6. Evolution of SS in raw wastewater (a) and treated effluent (b) 
SS concentrations in treated effluent showed a marked variability from a month to another (Fig. 6b). Maxima appeared independent of upstream values. Statistical analysis show also lack linearity $\left(R^{2}=0.0272\right)$ between raw wastewater and treated effluent. This testifies a particular behaviour of SS in the plant. The aeration conditions of wastewaters in the aeration tanks are probably the main factor of this SS behaviour.

\subsubsection{Bacteria}

Faecal indicator organisms (FIO) have been extensively used to evaluate water quality and have historically led to the public health protection concepts. Based on the monthly measurements performed in the studied plant from 2008 to 2010 , the results showed a trend of faecal coliform characterized by two antagonistic evolution phases in raw wastewater (Fig. 7a): the first is represented by an increasing rate and relatively significant monthly average densities around $5.54 \log$ MPN/100 ml while the second showed a decreasing rate and monthly average densities close to $5.27 \log$ MPN/100 ml. Maximum densities of 5.95, 6.25, 6.2 and 6.17 $\log$ MPN/100 ml are observed in January, February, March and April 2009, respectively. This may be attributed to the increase of human activities and the decrease of domestic water consumption (El-Taweel et al., 2002; ElKhateeb et al., 2009).
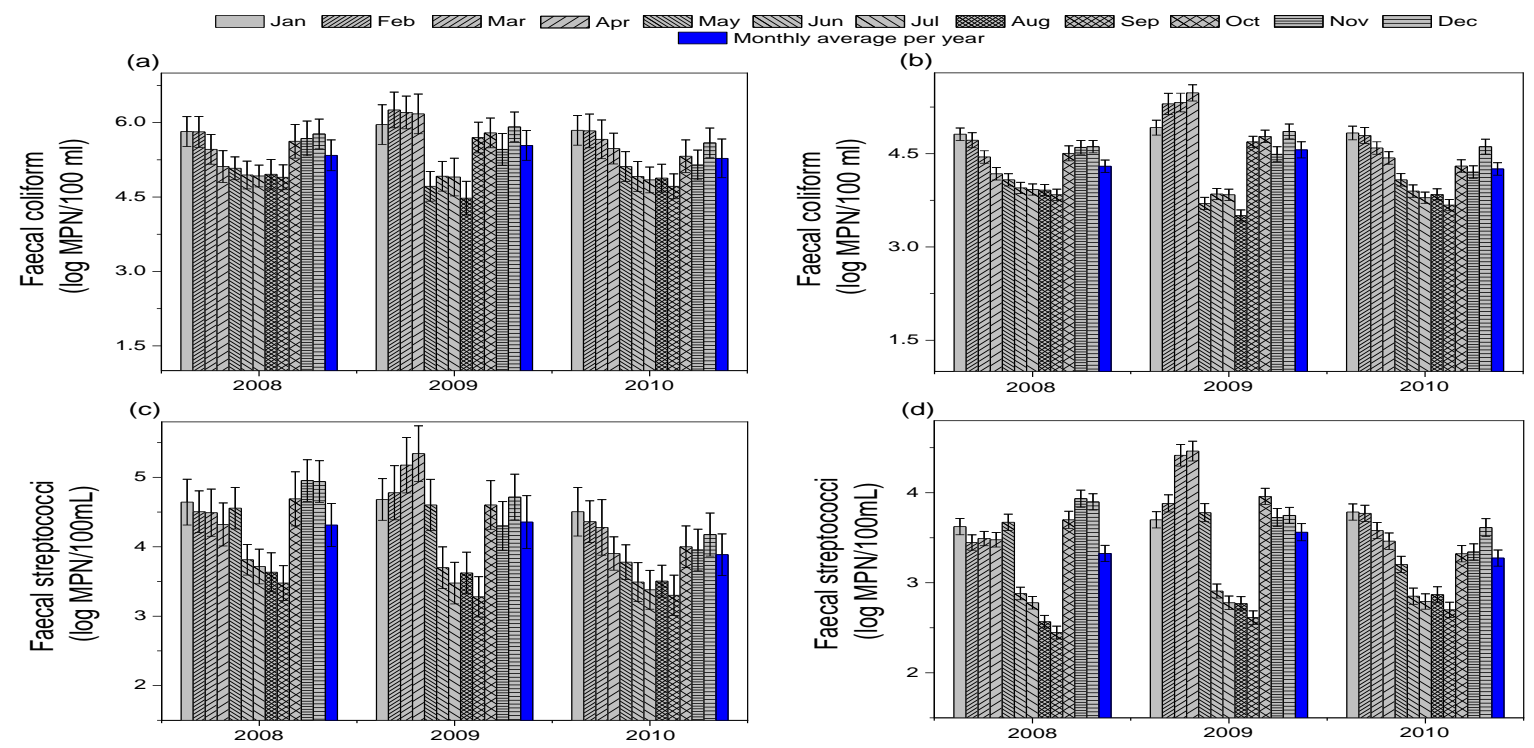

Figure 7. Evolution of FC in raw wastewater (a) and treated effluent (b), and evolution of FS in raw wastewater (c) and treated effluent (d)

The log average of MPN counts $100 \mathrm{ml}^{-1}$, in treated effluent showed the similar trend as in raw wastewaters (Fig. 7b). Statistical analysis show a close relationship $\left(\mathrm{R}^{2}=0.9788\right)$ between raw wastewater and treated effluent. Therefore, monthly densities in treated effluent are dependent of upstream conditions. Over the studied period, despite the conformity of upstream densities to the recommendations (Garcia \& Servais, 2006; Jamwal et al., 2009), the downstream densities are not enough to achieve a final effluent that would meet the Tunisian standards faecal bacteria limit for use of treated wastewater in agricultural unrestricted irrigation (3 log MPN/100 ml). It indicates that a considerable number of microbes were free in the water and could not be removed significantly by activated sludge process. Therefore, an additional treatment step is required to remove microorganisms more effectively.

Average faecal streptococci densities in raw wastewater also varied between 2008 and 2010 (Fig. 7c). Its general trend is similar to that of faecal coliform. It is characterized by two antagonistic evolution phases: the first is represented by an increasing rate and relatively significant monthly average densities around $4.35 \mathrm{log}$ MPN/100 ml while the second shows a decreasing rate and monthly average densities close to $3.9 \log$ MPN/100 ml. Maximum densities of 5.17 and $5.34 \log$ MPN/100 ml are observed in March and April 2009, respectively.

In treated effluent, the monthly average faecal streptococci densities showed the similar trend as in raw wastewater (Fig. 7d). However, monthly densities in treated effluent are dependent of upstream conditions $\left(\mathrm{R}^{2}=\right.$ 0.901). Furthermore, faecal streptococci reductions were not enough to achieve a final effluent that would meet the Tunisian guidelines faecal bacteria limit for use of treated wastewater in agricultural irrigation. 


\subsubsection{Nutrients}

Nitrogen is an important indicator of water pollution and its high concentration in freshwater bodies leads to eutrophication problem. Average TKN values in raw wastewater varied between 2008 and 2010 (Fig. 8a). Its general trend is characterized by an increasing rate from 48.32 to $60.91 \mathrm{mg} / \mathrm{L}$.
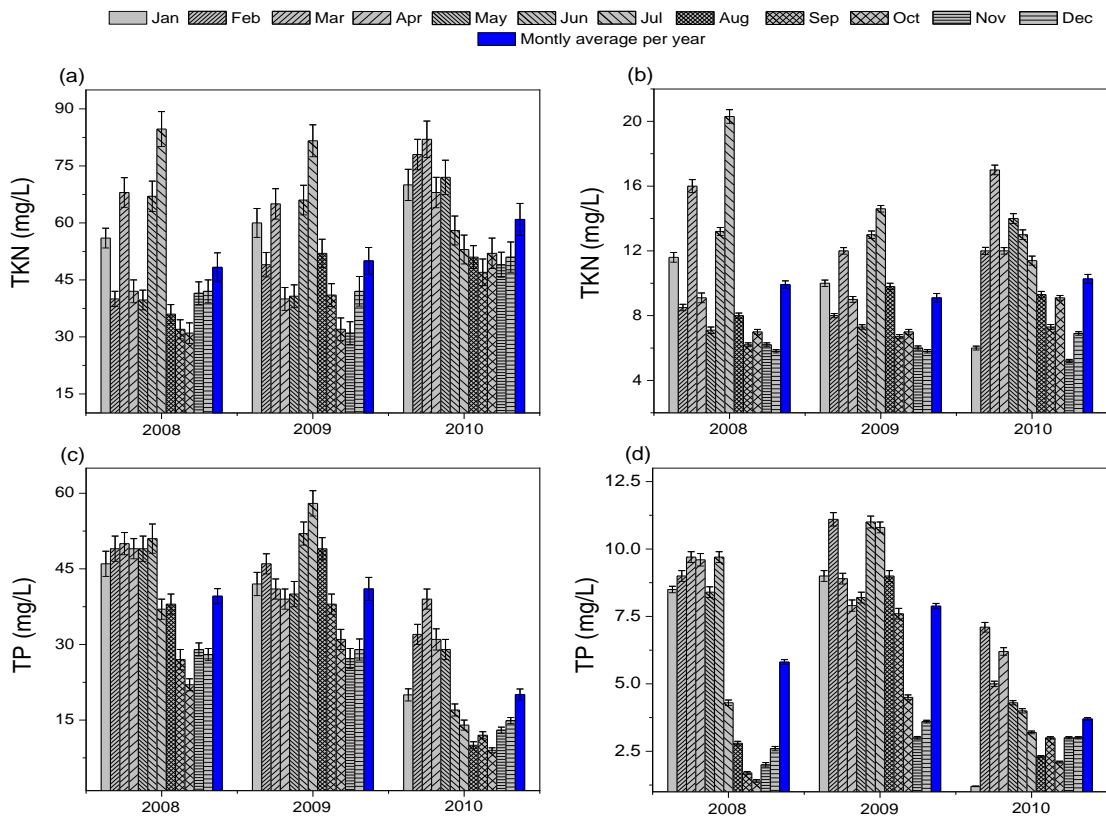

Figure 8. Evolution of TNK in raw wastewater (a) and treated effluent (b), and evolution of TP in raw wastewater (c) and treated effluent (d)

The variation of monthly average TKN values, in treated effluent showed a trend which is not consistent with that of raw wastewaters (Fig. 8b). Furthermore, the correlation between raw wastewater concentration and treated effluent concentration of TKN was less significant $\left(\mathrm{R}^{2}=0.6804\right)$. This further ensures the independence of downstream conditions on the upstream conditions. Considering the nitrogen removal (79 $83 \%$ ), the $\mathrm{pH}$ appears to be a significant parameter. Princic et al (1998) have shown that the optimal pH for the nitrification is between 6.5 and 8.5. During this study, $\mathrm{pH}$ values ranged between 7.5 and 7.6. Consequently, the problem shown for the nitrogen removal process is probably not related to the $\mathrm{pH}$ values. This problem could be attributed to the oxygen limitation in the aeration tanks, since nitrification is sensitive to the oxygen availability. The concentration of oxygen, during the studied period, did not exceed $2 \mathrm{mg} \mathrm{O}_{2} / \mathrm{L}$. In fact, we recorded high ammonium concentration in the treated effluent, in comparison to the little amount of both nitrite and nitrate (data not shown). The non-reduced ammonia forms could be explained by the existence of uncompleted nitrification during cyclic anoxic/aerobic operation attributed to the transition of anoxic and aerobic condition, on the other hand, Vaillant et al (2004) reported that the nitrification process is affected by the BOD level of the wastewater because of the competition for available oxygen between the nitrifying bacteria and the microorganisms removing biodegradable organic matter.

Phosphorus $(\mathrm{P})$ is a key nutrient which could be present in the environment in different forms: orthophosphate, polyphosphate and organic phosphorus (Sincero, 2003). The principal phosphorus compounds in wastewaters are generally orthophosphates often linked to smaller amounts of organic phosphorus (Grubb et al., 2000). The concentrations of phosphorus most often encountered in domestic and industrial wastewaters range between 3 and $15 \mathrm{mg} / \mathrm{l}$ (Sincero, 2003), whereas the maximum value of $1.0 \mathrm{mg}$ Total Phosphore/l is recommended for effluent discharge in many municipal and industrial wastewater treatment plants (Dartois \& Daboval, 1999). Average Total Phosphore values in raw wastewater also varied between 2008 and 2010 (Fig. 8c). Its general trend is not similar to that of NTK. It is characterized by two antagonistic evolution phases: the first is represented by an increasing rate and relatively significant monthly average values around $41 \mathrm{mg} / \mathrm{L}$ while the second shows a decreasing rate and monthly average values close to $20 \mathrm{mg} / \mathrm{L}$. Maximum values of 52 and $58 \mathrm{mg} / \mathrm{L}$ are observed in Jun and July 2009, respectively.

The variation of monthly average TP values, in treated effluent showed the same trend as in raw wastewater (Fig. 8d). On the basis of the high value of $\mathrm{R}^{2}(0.7489)$, it is suggested that monthly values in treated effluent are dependent on upstream conditions. Moreover, the mean monthly treated effluent TP levels (ranging of 3.7 to $5.80 \mathrm{mg} / \mathrm{L})$ don't met the minimum discharge Tunisian standard $(1 \mathrm{mg} / \mathrm{L})$. 
From this descriptive study, our findings showed that the performance of the plant after its rehabilitation is affected by multiple factors such as the population civilization, the inlet wastes quality, the rainwater, and the aeration conditions. Moreover, besides the above mentioned intrinsic and extrinsic factors, the plant performance would be affected by the industrial fallouts and deposits (Azri et al., $2007 \& 2009$ ). The application of simple correlation analysis is insufficient to evaluate the simultaneous effects of multiple factors on plant characteristics because this analysis tests the relationship between a single independent parameter and a dependent parameter at a time and consequently fails to elucidate combined effects of multiple factors. Therefore, multivariate analysis including, multiple regressions and predictive models, were performed.

\subsection{Multiple regression and predictive models}

A linear multivariate regression model estimates the behaviour of a dependent variable based on several independent variables, provided that a linear relation exists between the dependent variable and the rest of parameters. The result of this analysis is a linear equation $\left(y=\mathrm{ax}_{1}+\mathrm{bx}_{2}+\mathrm{cx}_{3}+\ldots+\mathrm{d}\right)$. In the present work, the forward stepwise method was particularly conducted to test the relationship between each of the changes of $\mathrm{BOD}_{5}, \mathrm{COD}$ and SS removal efficiencies and other variables. The independent variables included in the model were the temperature $\left({ }^{\circ} \mathrm{C}\right), \mathrm{pH}, \mathrm{CODw} / \mathrm{BOD}_{5} \mathrm{w}$ and rain water, as well as the influent and the effluent loading rates of $\mathrm{COD}, \mathrm{BOD}_{5}, \mathrm{SS}$ and MLSS. For each of the variables entered in the model, the forward selection calculates the $F$ statistic reflecting the contribution of the test variable to the model. For the entrance of the variables into the model, a rather liberal significance level $(p=0.5)$ has been selected to ovoid the elimination of the significant factor. This procedure calculates the coefficient of determination $\left(\mathrm{R}^{2}\right)$ for all models.

Table 2 and Fig. 9 depict predictive models constructed for predicting removal efficiencies of $\mathrm{BOD}_{5}$, COD and SS and predicted values against measured ones are plotted.

Table 2. Predictive models and evaluation of fit

\begin{tabular}{llcc}
\hline Dependant variables & \multicolumn{1}{c}{ Predictor independent variables } & Constant & $\mathrm{R}^{2}$ \\
\hline BOD5r & $0.016\left(\mathrm{BOD}_{5} \mathrm{w}\right)-0.182\left(\mathrm{BOD}_{5} \mathrm{t}\right)+0.028(\mathrm{CODt})$ & 93.556 & 0.973 \\
$\mathrm{CODr}$ & $0.008(\mathrm{CODw})-0.058(\mathrm{COD})+0.004\left(\mathrm{BOD}_{5} \mathrm{w}\right)$ & 89.418 & 0.946 \\
& $-0.030(\mathrm{SSt})$ & 79.983 & 0.925 \\
$\mathrm{SSr}$ & $12.808\left(\mathrm{CODw} / \mathrm{BOD}_{5} \mathrm{~W}\right)+0.040\left(\mathrm{BOD}_{5} \mathrm{w}\right)$ & & \\
& $-0.019(\mathrm{CODw})-1.459(\mathrm{pHt})-0.173(\mathrm{SSt})$ & &
\end{tabular}

$\mathrm{R}$ : removal efficiency; w: raw wastewater; t: treated effluent.

Our results showed that $97.3 \%\left(\mathrm{R}^{2}=0.973\right)$ of the total variation in the removal efficiency of BOD5 (dependent variable) could be explained by the biological oxygen demand concentrations in raw wastewater, the biological oxygen demand concentrations in treated effluent and the chemical oxygen demand concentrations in treated effluent. Nevertheless, it is also important to know the influence of a particular independent variable on the explanation of that variation that cannot be explained by the other independent variables. Therefore, partial analyses using variance partition were performed, where a single independent variable was included, while the others were used as covariables. Hence, successively, it was observed that the biological oxygen demand concentrations in raw wastewater was the most determining independent variable (explaining by its own $9.5 \%$ of the total variation in the change of BOD5 removal efficiency), followed by the chemical oxygen demand concentrations in treated effluent $(9.4 \%)$ and, finally, the biological oxygen demand concentrations in treated effluent $(3.7 \%)$. The sum of all these partial percentages $(22.6 \%)$ is lower than the value obtained when all the independent variables were considered in the analysis (97.3\%). This happens when independent variables are correlated, and their effects are not easy to separate. Because of this, the remaining percentage of explanation $(74.7 \%)$ cannot be clearly attributed to an individual independent variable. 


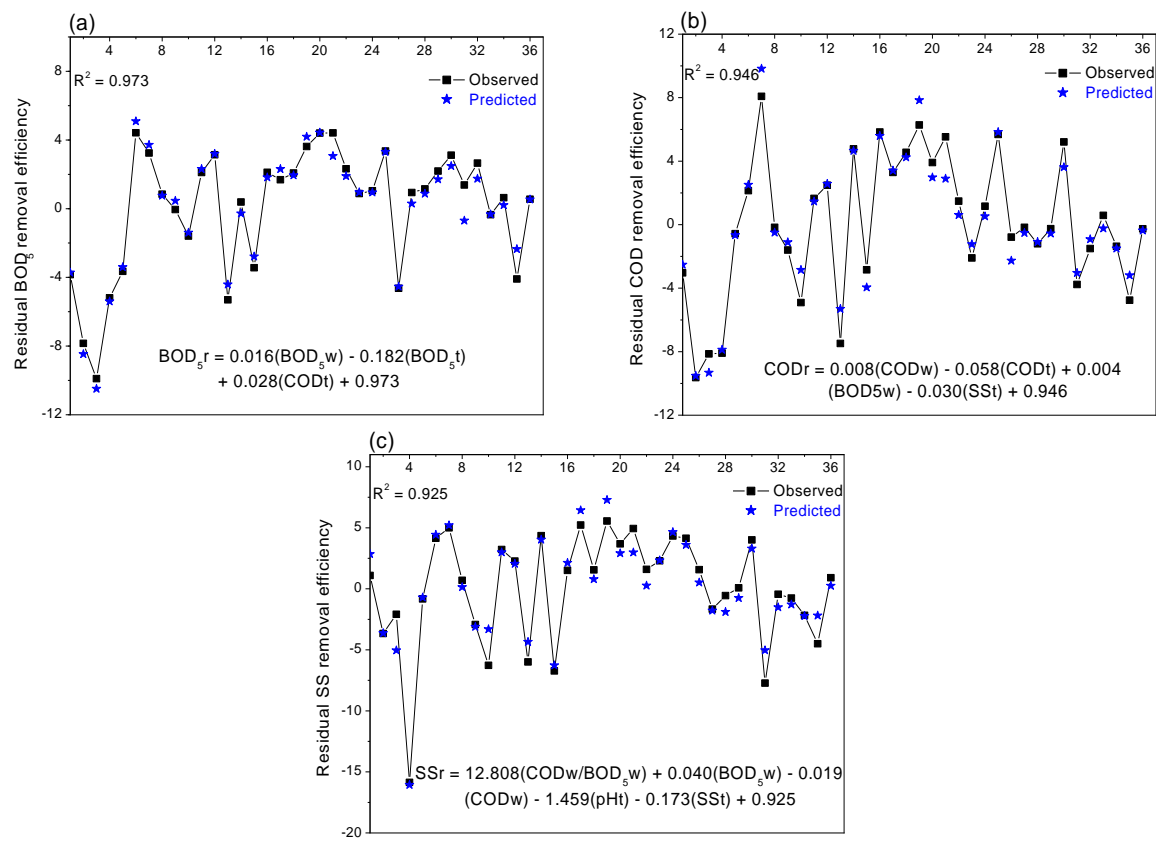

Figure 9. Residual plots of predicted and observed values of BOD5r (a), CODr (b) and $\mathrm{SSr}$ (c) during three years period. the predicted values were obtained by using the equation model indicated under each graph

For COD prediction, model explains $94.6 \%$ of the observed COD removal efficiency. However, $94.6 \%$ of the total variation in the removal efficiency of COD (dependent variable) could be explained by the chemical oxygen demand concentrations in raw wastewater, the chemical oxygen demand concentrations in treated effluent, the biological oxygen demand concentrations in raw wastewater and the suspending solid concentrations in treated effluent. The percentages of the influence were $9.3 \%, 8.1 \%, 2.9 \%$ and $1.3 \%$, respectively.

Regarding to the SS prediction, model explains $92.5 \%$ of the observed SS removal efficiency. This, $92.5 \%$ of the total variation in the removal efficiency of SS (dependent variable) could be explained by the $\mathrm{CODw} / \mathrm{BOD}_{5} \mathrm{w}$ ratio, the biological oxygen demand concentrations in raw wastewater, the chemical oxygen demand concentrations in raw wastewater, the $\mathrm{pH}$ in treated effluent, the suspending solid concentrations in treated effluent and the suspending solid concentrations in raw wastewater. The percentages of the influence were $25.5 \%, 23.4 \%, 21 \%, 12.5 \%, 7.5 \%$ and $4.1 \%$, respectively.

The applicability of the models, as practical prediction tools for the changes of $\mathrm{BOD}_{5}, \mathrm{COD}$ and SS removal efficiencies, were tested by comparing the residuals (observed values minus average series values) of observed and their corresponding values predicted by the model (Fig. 9). The scatter plots indicated a strong positive linear relationship between the observed and predicted variables with $r^{2}$ values of $0.986,0.973$ and $0.961(\mathrm{n}=36)$ for $\mathrm{BOD}_{5} \mathrm{r}, \mathrm{CODr}$ and $\mathrm{SSr}$, respectively.

\section{Conclusions}

In this study, performance of activated sludge process adopted by Sfax sewage treatment plant was evaluated. Despite the rehabilitation, descriptive analysis of water quality parameters evolution showed a particular behaviour of mineral and organic matter in the wastewater. It is affected by multiple intrinsic and extrinsic factors such as the raw wastewater quality, the variation of the population activities, the aeration conditions and the industrial fallouts and deposits.

Thus, the multivariable regression analysis surrounded the individual impacts of aforementioned factors on plant characteristics and proved their simultaneous effects. Models were building to predict the removal efficiencies of COD, BOD5 and SS, so as to evaluate the performance of the plant.

Model developed for predicting removal efficiency of biochemical oxygen demand, chemical oxygen demand and suspending solid proved strong which cover a range of data for the training, validation, and testing purposes.

\section{Acknowledgments}

The authors would like to thank the local authorities in Tunisia for kindly allowing us to take wastewater samples. The authors would like thank a second reviewer for effort provided in statistical analysis. 


\section{References}

[1]. AFNOR. NF T90-411. (1989). Essais des eaux - Recherche et dénombrement des Streptocoques du groupe D - Méthode générale par ensemencement en milieu liquide (NPP). $472-80$

[2]. Association française de normalisation. (1997). Recueil des normes AFNOR, Qualité de l'eau, Méthodes d'analyse (4 ème tome), 2 ème Ed.

[3]. Azri, C., Abida, H. and Medhioub, K. (2007). Performance evaluation of the Wastewater treatment plant of Sfax city (Tunisia): influence of intrinsic and extrinsic factors. Asian journal of Water, Environment and Pollution, 5 (3), 35 - 47.

[4]. Azri, C., Abida, H. and Medhioub, K. (2009). Geochemical behaviour of the Tunisian background aerosols in sirocco w............. Advances in atmospheric sciences, 26 (3), 390 - 402.

[5]. Azri, C., Maalej, A., Medhioub, K. and Rosset, R. (2007). Evolution of atmospheric pollutants in the citty of Sfax (Tunisia) (October 1996 - June 1997). Atmosphera, 20 (3), 223 - 242.

[6]. Berwick, L.J., Greenwood, P.F., Kagi, R.I. and Croué, J.P. (2007). Thermal release of nitrogen organics from natural organic matter using micro-scale sealed vessel pyrolysis. Org. Geochem, 38, $1073-1090$.

[7]. Dartois, J. and Daboval, B. (1999). 25 ans d'assainissement des eaux usees industrielles au Quebec: un bilan, Gouvernement du Quebec, Service de l'assainissement des eaux, Direction des politiques du secteur industriel, Quebec, Canada.

[8]. Dione, I. (2002). Expériences de l'ONAS dans le choix et la gestion des stations de lagunage au Sénégal, séminaire CEREVEEIER Traitement des eaux usées par lagunage: challenges et perspectives pour les pays en voie de développement 4 November 2002, Ouagadougou.

[9]. El-Khateeb, M.A., Al-Herrawy, A.Z., Kamel, M.M. and El-Gohary, F.A. (2009). Use of wetlands as post-treatment of anaerobically treated effluent. Desalination, 245, $50-59$.

[10]. El-Taweel, G.E., Shaban, A.M., El-Hawaary, S. and El-Gohary, F.A. (2002). Microbiological characteristics of wastewater in Egypt:II-treated effluent. Egyptian Journal of Microbiology, 35, 239 - 256.

[11]. Garcia-A.T. and Servais, P. (2006). Respective contribution of point and non-point sources of E. coli and Enterococci in large urbanized watershed (the seine river, France). Journal of Environmental Management, 82, 512 - 518.

[12]. Grubb, D.G., Guimaraes, M.S. and Valencia, R. (2000). Phosphorus immobilization using an acidic type F fly ash. J. Hazard. Mater, 76, $217-236$.

[13]. Hachicha, S., Cegarra, J., Sellami, F., Hachicha, R., Drira, N., Medhioub, K. and Ammar, E. (2009). Elimination of polyphenols toxicity from olive mill wastewater sludge by its co-composting with sesame bark, J. Hazard. Mater, 161, 1131 - 1139.

[14]. Hamed, M., Khalafallah, M.G. and Hassanein, E.A. (2004). Prediction of wastewater treatment plant performance using artificial neural network, Environmental Modeling and Software, 19, 919 - 928.

[15]. Hanbay, D., Turkoglu, I. and Demir, Y. (2008). Prediction of wastewater treatment plant performance on wavelet packet decomposition and neutral networks. Expert Sys with Appl, 34, 1038 - 1043.

[16]. ISO 4832. (1991). Microbiologie alimentaire - directives générale - dénombrement des coliformes - méthode par comptage des colonies.

[17]. Jamwal, P., Mittal, A.K. and Mouchel, J. (2009). Efficiency evaluation of sewage treatment plants with different technologies in Delhi (India). Environmental Monitoring and Assessment, 153, 1 - 4.

[18]. Ministère de l'Agriculture et des Ressources Hydrauliques, Tunisie. (2008). Campagne 2008 de la récolte des olives, Sfax.

[19]. Ouali, A., Azri, C., Medhioub, K. and Ghrabi, A. (2009). Descriptive and multivariable analysis of physico-chemical and biological parameters of Sfax wastewater treatment plant. Desalination, 246, 496 - 505.

[20]. Patricia, A., Jones, J.A. and Schuler (2010). Seasonal variability of biomass density and activated sludge setteability in full-scale wastewater treatment systems. Chemical engineering journal, 164, 16 - 22.

[21]. Princic, A., Mahne, I., Megusar, F., Paul, E.A. and Tiedje, J.M. (1998). Effects of the pH and oxygen and ammonium concentrations on the community structure of nitrifying bacteria from wastewater. Appl. Environ. Microbiol, 64, $3584-3590$.

[22]. Sincero, G.A. (2003). Physical-chemical Treatment of Water and Wastewater. CRC Press, Boca Raton, Florida, 832.

[23]. STATIT-CF. (1987). Services des études statistiques de l'Institut Technique des Céréales et Fourrages (I.T.C.F). Boigneville.

[24]. Vaillant, N., Monnet, F., Sallanon, H., Coudret, A. and Hitmi, A. (2004). Use of commercial plant species in a hydroponic system to treat domestic wastewaters. J. Environ. Qual, 33, 695 - 702. 